Литвинова Світлана Григорівна

кандидат педагогічних наук, старший науковий співробітник

Інститут інформаційних технологій і засобів навчання НАПН України, м. Київ, Україна

s_litvinova@i.ua

\title{
ТЕХНОЛОГІЇ НАВЧАННЯ УЧНІВ У ХМАРО ОРІЕНТОВАНОМУ НАВЧАЛЬНОМУ СЕРЕДОВИЩІ ЗАГАЛЬНООСВІТНЬОГО НАВЧАЛЬНОГО ЗАКЛАДУ
}

\begin{abstract}
Анотація. У статті проаналізовано технологію «перевернутого» навчання, 3'ясовано особливості даної технології, здійснено порівняння 3 традиційним навчанням, описано особливості використання технології вчителем й учнями, розроблено технологічну карту підготовки до уроку вчителя й учня, встановлено, що компонент хмаро орієнтованого навчального середовища Lync (Skype Pro) може використовуватися для розробки відеофрагментів з метою реалізації технології «перевернутого» навчання.

Автором дано визначення поняттю «технологія веб-квест», узагальнено компоненти структури веб-квесту, визначено функції, види завдань, що розв’язуються з використанням даної технології, здійснено класифікацію веб-квестів. Встановлено, що у хмаро орієнтованому навчальному середовищі закладено всі можливості для реалізації технології веб-квесту.
\end{abstract}

Ключові слова: хмаро орієнтоване; навчальне середовище; технології; «перевернуте» навчання; веб-квест; ХОНС.

\section{1. ВСТУП}

Постановка проблеми. 3 розвитком новітніх технологій учителям стає все складніше підтримувати інтерес учнів до навчання. Вони мають створювати новітні умови і ситуації, за якими кожен учень залучатиметься до навчального процесу, що сприятиме його всебічному розвитку. Тому дослідження проблеми навчальної мотивації учнів загальної середньої школи було і залишається актуальним.

Нині вчителі здійснюють активний пошук механізмів і технологій залучення учнів до навчальної діяльності, що обумовлено необхідністю формуванням як їхніх предметних, навчальних, так і життєвих компетентностей. Такими механізмами можуть бути новітні технології навчання.

Тому переважна більшість педагогів розробляє умови для персоналізованого навчання, використовуючи такі засоби, як відео, електронні освітні ресурси, комп'ютерні ігри.

Однак, якщо традиційна модель навчання не буде змінюватися, то такі технології матимуть обмежений ефект.

3 розвитком інформаційно-комунікаційних технологій, зокрема хмаро орієнтованих навчальних середовищ (ХОНС), розвиваються нові можливості щодо реалізації спільної роботи учнів і вчителя [16].

Технології навчання, що реалізуються у хмаро орієнтованому навчальному середовищі для активізації навчальної діяльності учнів загальноосвітніх навчальних закладів - «перевернуте» навчання і веб-квест.

Дидактичні можливості технологій, що використовуються у хмаро орієнтованому навчальному середовищі, полягають у створенні привабливого й інтерактивного навчального простору для учнів. За допомогою використання цих технологій у хмаро 
орієнтованому навчальному середовищі вдається розгорнути освітній процес шляхом об'єднання учасників у єдину мікро або макро соціальну навчальну мережу [1].

Перспективність ідеї впровадження в освітню практику таких передових педагогічних технологій обумовлено потребою формування в сучасних учнів навичок самостійно розв'язувати актуальні проблеми, критично мислити, підвищувати інтелектуальний рівень, розширювати світогляд i, як наслідок, формувати компетентності, необхідні для ефективної діяльності і комунікації у XXI столітті [5].

Враховуючи той факт, що проблема використання технологій «перевернутого» навчання і веб-квесту у хмаро орієнтованому навчальному середовищі в системі загальної середньої освіти недостатньо розкрита науковою спільною, доцільно звернутися до вивчення, аналізу цього питання.

Аналіз останніх досліджень і публікацій. Технологія «перевернуте» навчання $\epsilon$ досить новим явищем в освіті, проте зумовлює значний інтерес серед науковців, зокрема закордонних, і відображена у працях таких учених, як Басалгіна Т. Ю. [2], Курвітс М. [15], Ремізова О. Г. [22], Бейкер С. (Baker Celia) [31], Бергман Дж. (Bergmann J.) [32], Семс A. (Sams A.) [32], Беррет Д. (Berrett D.) [33], Дрісколл T. (Driscoll Tom) [36], Горман M. (Gorman M.) [37], Грин Г. (Green G.) [38], Маршал Г. В. (Marshall H. W.) [42] та ін.

Питання розвитку технології веб-квесту у навчальному процесі активно досліджуються вітчизняними і зарубіжними вченими: Багузіною О. I.[1], Бондаренком Т. М.[3], Волковою О. В.[5], Гапеєвою О. Л.[6], Гончаровою Н. Ю.[8], Грабчаком Д. В. [9], Гриневич М. С.[10], Зайкіним М. І.[11], Кадемією М. Ю.[12], Карун I. О. [26], К Кононець Н. В.[13], Кузнєцовою Т. О.[14], Колесніченко В. Л.[26], Мосіною М. О.[18], Ніколайчуком І. В.[20], Ніколаєвою Н. В.[19], Новіковою А. О.[26], Полат Є. С.[21], Сокол I. М. [23, 24, 25], Шмідт В. В.[29], Шевцовою О. Г.[28], Шаматоновою Г. Л. [27], Федоровим О. В. [26], Доджем Б.[35], Лемб А. (Lamb A.) [39], Лоуренсом Л. (Laurence L.) [40], Марч T. (March T.) [41], Роджерс C. (Rogers C.R.) [43], Стерн H. (Stern H.H.) [44] та ін.

Актуальні питання проектування, використання та розвитку хмаро орієнтованих навчальних середовищ досліджуються Биковим В. Ю., Жалдаком М. І., Носенко Ю. Г., Сейдаметовою 3. С., Семеріковим С. О., Стрюком А. М., Морзе Н. В., Шишкіною М. П. та ін.

Проте, аналіз результатів дослідження щодо проектування хмаро орієнтованих навчальних середовищ свідчить про недостатню вивченість питання використання технологій «перевернутого» навчання і веб-квесту у хмаро орієнтованому навчальному середовищі загальноосвітніх навчальних закладів.

Мета статті полягає в узагальненні методики використання технологій «перевернутого» навчання і веб-квесту у хмаро орієнтовному навчальному середовищі загальноосвітнього навчального закладу.

\section{2. МЕТОДИ ДОСЛІДЖЕННЯ}

Дослідження проводилось у рамках НДР №0115U002231 «Методологія формування хмаро орієнтованого навчально-наукового середовища педагогічного навчального закладу» Інституту інформаційних технологій і засобів навчання НАПН України, Всеукраїнського проекту «Хмарні сервіси в освіті» 2014-2017 н. р. (Наказ МОН України від 21.05.2014 р. № 629). Під час дослідження використовувались такі методи: аналіз теоретичних джерел, вивчення передового педагогічного досвіду зарубіжних i вітчизняних педагогів 3 проблеми використання технологій 
«перевернутого» навчання і веб-квесту, узагальнення й оцінювання отриманих результатів.

\section{3. РЕЗУЛЬТАТИ ДОСЛІДЖЕННЯ}

Виклад основного матеріалу. Нині особлива увага суспільства приділяється метапредметним результатам освітньої діяльності, що передбачають формування i розвиток особистісних якостей і загальної культури учнів, розуміння цінності освіти, внутрішньої мотивації і відповідальності за своє навчання.

В організації навчального процесу сучасної школи мають бути враховані як тенденції розвитку науки й техніки, так і вимоги суспільства до якості надання освітніх послуг.

Одним із найефективніших шляхів для виконання такого завдання цілком правомірно вважати цілеспрямоване використання інформаційно-комунікаційних технологій і електронних засобів у навчально-виховному процесі [7, с. 234].

Використання сучасних IКТ дозволяе не тільки урізноманітнити навчальновиховний процес, а й упровадити нові педагогічні технології навчання, зокрема «перевернуте» навчання. За цією технологією під час підготовки до уроку учні використовують відео й електронний контент за межами навчального закладу - у хмаро орієнтованому навчальному середовищі.

Під хмаро орієнтованим навчальним середовищем (ХОНС) ми розуміємо штучно побудовану систему, щчо за допомогою хмарних сервісів забезпечує навчальну мобільність, групову співпрацю педагогів та учнів для ефективного, безпечного досягнення дидактичних ичілей [16].

Використання технології «перевернутого» навчання створює учням умови повсюдного доступу до навчальних ресурсів, комунікації 3 однокласниками й учителями, співпраці в навчанні і проектній діяльності, і розкриває можливості для особистісного розвитку.

«Перевернуте» навчання (англ. flipped learning) - це технологія здійснення процесу навчання, у якому передбачається, що учні за допомогою різноманітних гаджетів прослуховують і переглядають відеоуроки, вивчають додаткові джерела самостійно (у позаурочний час), а потім у класі всі разом обговорюють нові поняття i різні ідеї, а вчитель допомагає застосовувати отримані знання на практиці. Організація навчання спонукає учнів вчитися один у одного.

Розглянемо особливості і порівняємо технології «перевернутого» і традиційного навчання (табл. 1).

Особливості «перевернутого» навчання:

- змінюється роль учителя, який перетворюється на наставника. Роль учителя все ж залишається провідною, але його діяльність спрямовується на координацію навчання учнів, здійснення консультування, надання допомоги та створення навчальнопроблемної ситуації для пізнавально-дослідницької діяльності;

- використовуються електронні освітні ресурси. Завдяки сучасним технологіям учителями накопичена велика база різноманітних матеріалів таких, як відео, інтерактивні завдання, електронні навчальні матеріали, електронні тести для самоперевірки; книжки вже не є єдиним джерелом інформації, а вчителі єдиними джерелами знань. Кожен, хто має доступ до мережі Інтернет, може отримати якісний електронний освітній контент у зручний для нього час;

- підвищуються вимоги до навчальної діяльності учнів. Теоретична частина навчального матеріалу має формувати в учнів базові поняття і підтримувати навчання, а не займати центральне місце. Зміст навчання вже не є самоціллю, а стає відправною 
точкою поглиблення знань. Здійснюється зміщення акценту на процес пізнавальної діяльності учнів, у ході якої він відкриває для себе нові знання;

- розв'язуються різнопланові проблеми навчання в обговореннях $i$ дискусіях. Технологія «перевернуте» навчання дає можливість учителеві вивільнити час для спілкування з учнями на уроці. Фактично, з'являється можливість працювати з учнем один на один. Учитель може приділити більше уваги тим учням, яким важко дається навчальний предмет або у яких виникають проблеми з виконанням домашніх робіт. Обдаровані учні матимуть більше свободи для того, щоб навчатися у власному темпі. Використання технології «перевернутого» навчання сприяє реалізації персоналізованого підходу в навчанні.

Таблиияя 1

\section{Порівняння «перевернутого» і традиційного навчання}

\begin{tabular}{|c|c|c|}
\hline $\begin{array}{c}\text { Навчальний } \\
\text { процес }\end{array}$ & «Перевернуте» навчання & Традиційне навчання \\
\hline $\begin{array}{l}\text { Підготовка до } \\
\text { уроку }\end{array}$ & $\begin{array}{l}\text { Перегляд відповідей на тести, } \\
\text { визначення «важких» для учнів } \\
\text { питань, відбір тренувальних і } \\
\text { розвивальних завдань }\end{array}$ & $\begin{array}{l}\text { Написання конспекту уроку, } \\
\text { підготовка тренувальних і } \\
\text { розвивальних завдань }\end{array}$ \\
\hline $\begin{array}{l}\text { Технологія } \\
\text { проведення } \\
\text { уроку }\end{array}$ & $\begin{array}{l}\text { Учитель спрямовує діяльність } \\
\text { учнів на розв’ язання «важких» } \\
\text { для них питань і відпрацювання } \\
\text { навичок }\end{array}$ & $\begin{array}{l}\text { Учитель пояснює новий матеріал, } \\
\text { учні закріплюють отримані } \\
\text { навички }\end{array}$ \\
\hline $\begin{array}{l}\text { Технологія } \\
\text { навчання }\end{array}$ & $\begin{array}{l}\text { Дома учні самостійно } \\
\text { переглядають відео, ЕОР, } \\
\text { виконують тестові завдання, } \\
\text { готують запитання вчителю. } \\
\text { Учитель спрямовує діяльність } \\
\text { учнів на розв’язання «важких» } \\
\text { питань і відпрацювання навичок }\end{array}$ & $\begin{array}{l}\text { Учитель пояснює новий матеріал, } \\
\text { учні в класі закріплюють } \\
\text { отримані навички. } \\
\text { Дома виконують завдання } \\
\text { самостійно }\end{array}$ \\
\hline $\begin{array}{l}\text { Передача } \\
\text { знань }\end{array}$ & $\begin{array}{l}\text { Учень здобуває знання } \\
\text { самостійно, з’ясування ж } \\
\text { «важких» питань здійснюється з } \\
\text { використанням технологій } \\
\text { інтерактивного навчання }\end{array}$ & $\begin{array}{l}\text { Навчальний матеріал від учителя } \\
\text { до учня передається у формі } \\
\text { пасивного сприйняття, потім } \\
\text { учитель у класі організовує } \\
\text { діяльність учнів } 3 \text { його засвоєння }\end{array}$ \\
\hline Методи & $\begin{array}{l}\text { Інтерактивні технології, } \\
\text { інформаційно-повідомні, } \\
\text { що дозволяють учню самостійно } \\
\text { здобувати знання }\end{array}$ & $\begin{array}{l}\text { Інтерактивні технології, що } \\
\text { дозволяють учню здобувати } \\
\text { знання у процесі взаємодії } \\
\text { вчитель-учень }\end{array}$ \\
\hline Підходи & $\begin{array}{l}\text { Персоналізований і } \\
\text { диференційований }\end{array}$ & Диференційований \\
\hline IKT & Сервіси MS Office 365, Google, & Мультимедіа (дошка, проектор, \\
\hline
\end{tabular}




\begin{tabular}{|l|l|l|}
\hline & Web-2.0, Moоdle тощо & гаджет), локальні ЕОР тощо \\
\hline $\begin{array}{l}\text { Діяльність } \\
\text { учнів }\end{array}$ & Активна & Пасивна \\
\hline Роль учня & $\begin{array}{l}\text { Несе відповідальність за своє } \\
\text { навчання. Взаємодіє з усіма } \\
\text { учасниками навчального процесу }\end{array}$ & $\begin{array}{l}\text { Навчається за схемою послухай - } \\
\text { запам'ятай - відтвори }\end{array}$ \\
\hline Роль учителя & $\begin{array}{l}\text { Здійснює конструювання } \\
\text { навчальної діяльності, виконує } \\
\text { роль наставника }\end{array}$ & $\begin{array}{l}\text { Здійснює передачу і контроль } \\
\text { знань, підтимує дисципліну і } \\
\text { порядок у класі }\end{array}$ \\
\hline $\begin{array}{l}\text { Доступ до } \\
\text { навчальних } \\
\text { матеріалів }\end{array}$ & Повсюдний & У класі \\
\hline $\begin{array}{l}\text { Обговорення, } \\
\text { дискусії }\end{array}$ & Постійно & Періодично \\
\hline
\end{tabular}

Отже, саме у хмаро орієнтованому навчальному середовищі вчитель-предметник може створити умови для доступу учнів до навчальних матеріалів, активізації навчальної діяльності, реалізації технології «перевернутого» навчання, що базується на розв'язанні навчальних проблем в обговореннях і дискусіях.

Загальні переваги технології «перевернутого» навчання полягають у створенні умов для:

- реалізації диференційованого підходу в навчанні;

- сприяння активному навчанню;

- використання новітніх технологій і різноманітних гаджетів;

- організації освітнього процесу з урахуванням потреб кожного учня;

- командної роботи;

- розвитку лідерських якостей учнів;

- персоналізованого навчання;

- активної взаємодії вчителя й учня;

- доступу всіх учнів до матеріалів уроку будь-де і будь-коли;;

- діагностики якості знань за допомогою використання комп'ютерних технологій;

- залучення батьків до навчально-виховного процесу.

Переваги для учнів полягають у створенні умов для:

- здійснення соціалізації і командної роботи;

- навчання в позаурочний час;

- доступності якісних електронних освітніх ресурсів;

- підвищення інтересу до навчальних предметів;

- підвищення інтересу до групової роботи на уроці;

- навчання у власному темпі;

- підвищення відповідальності за своє навчання;

- допомоги один одному в навчанні;

- критичного оцінювання навчальних досягнень;

- розвитку ІКТ-компетентностей;

- використання гаджетів як інструменту навчання. 
Переваги для вчителя:

- учитель виступає в ролі наставника учнів, координатора пізнавальної діяльності; здійснює персоналізований підхід за рахунок вивільнення часу на уроці;

- забезпечує учнів якісними електронним освітнім контентом;

- забезпечує активізацію навчальної діяльності в позаурочний час;

- має можливість проводити більше часу один на один 3 тими учнями, які потребують додаткової підтримки і допомоги;

- залучає до різних видів робіт усіх учнів класу;

- використовує новітні форми організації навчальної діяльності;

- має можливість комп'ютерної діагностики якості знань учнів;

- підвищує свій рівень ІКТ-компетентностей.

Загальні особливості технології «перевернутого» навчання:

- вимагає більше часу для планування і підготовки вчителя;

- передбачає постійний доступ учнів до комп'ютерів і мережі Інтернет;

- труднощі залучення до навчального процесу окремих категорій учнів.

Особливості використання технології «перевернутого» навчання» для учня:

- більше часу проводить перед комп'ютером;

- нерівні можливості доступу до мережі Інтернет;

- проблеми використання різноманітних гаджетів;

- домашнє завдання є обов'язковою частиною уроку;

- важко звикнути до нової технології навчання.

Особливості використання технологї «перевернутого» навчання для вчителя:

$\mathrm{XOHC;}$

- здійснення первинного завантаження навчальних матеріалів великого обсягу в

- здійснення подальшого вдосконалення навчальних матеріалів;

- здійснення персоналізованого підходу;

- володіння різноманітними ІК-технологіями;

- володіння технологіями групової роботи засобами ІКТ;

- підтримка вчителя у використанні новітніх технологій керівниками навчального закладу.

Важливим компонентом у реалізації технології «перевернутого» навчання $\epsilon$ розробка стандартної технологічної карти підготовки до уроку вчителів і учнів.

Технологічна карта підготовки вчителя до уроку:

- сформувати завдання і визначити терміни його виконання;

- сформувати список нової лексики за темою для приведення у відповідність розуміння змісту навчального відео;

- відібрати (створити) навчальне відео або інші ЕОР;

- відібрати (створити) тестове завдання (вправу) за тематикою навчального відео або інших ЕOP;

- створити список запитань для контролю розуміння змісту навчального відео або інших EOP;

- розробити інструкції з граматичним або алгоритмічним матеріалом до уроку;

- відібрати завдання для роботи з підручником;

- прогнозувати можливий варіант зворотного зв'язку з учителем (електронною поштою або за допомогою використання миттєвих повідомлень).

Технологічна карта підготовки учня до уроку:

- ознайомитися із завданням і термінами його виконання;

- ознайомитися зі списком нової лексики для розуміння змісту навчального відео;

- переглянути навчальне відео;

- виконати тестове завдання (вправу) за тематикою навчального відео;

- здійснити пошук відповідей до списку запитань для самоконтролю розуміння змісту навчального відео; 
- прочитати інструкції з граматичним або алгоритмічним матеріалом до уроку;

- виконати завдання за підручником;

- здійснити електронну комунікацію з вчителем за потреби.

Технологія проведення «перевернутого» уроку:

- учитель записує пояснення нового матеріалу на веб-камеру, або робить запис за допомогою спеціальних програм;

- учитель розміщує навчальне відео в ХОНС або робить розсилання учням 3 посиланнями на матеріал, розміщений у YouTube;

- учні отримують як домашнє завдання навчальне відео, електронний освітній ресурс або опорний конспект для вивчення нового матеріалу;

- учні виконують он-лайн тест і завдання;

- на уроці вчитель організує навчальну діяльність, залучає до різних видів роботи всіх учнів класу;

- учні уважно переглядають навчальне відео, виконують завдання, формулюють питання, відпрацьовують навички.

Контроль та активізація навчальної діяльності учнів:

- початок заняття з короткого повторення або дискусії за матеріалами, що були представлені на відео або інших електронних освітніх ресурсах (ЕОР);

- перегляд записів учнів або відповідей на запитання (тести), пов'язані 3 відповідним матеріалом;

- використання он-лайн тестів і завдань для оцінювання навчальної діяльності учнів;

- система бліц-опитування, що спонукає учнів до зосередження уваги на навчанні.

Хмаро орієнтоване навчальне середовище слугує платформою для здійснення «перевернутого» навчання і забезпечує використання вчителем презентацій, опорних конспектів, новітніх навчальних відео, зокрема відеоуроків.

Як зазначає Глазунова О. Г., навчальне відео - це різноманітні аудіовізуальні засоби [7, с. 241]. Вони поділяються на: відеокліп, відеоурок, відеолекцію, відеокейс, науково-популярний відеофільм, художній фільм, анімаційний фільм, вебінар, скрінкаст.

У системі загальної середньої освіти для підготовки учнів до уроку тривалість відео має бути невеликою (до 5 хвилин), тому частіше за все вчителі використовують $\mathrm{i}$ самостійно створюють відеоуроки або відеофрагменти.

Глазунова О. Г. звертає увагу на те, що використання навчальних відеоресурсів дозволяє істотно підвищити ефективність навчального процесу. Проте, поряд 3 очевидними перевагами використання навчального відеоконтенту, є низка проблемних питань [7, с. 246]:

- для створення і використання відеоресурсів необхідно бути ІКТ-компетентним на рівні початківця, мати навички роботи з відеотехнікою і спеціальним програмним забезпеченням;

- створення відеоресурсів - процес, що вимагає серйозних часових затрат і знань 3 різних галузей науки;

- зловживання спецефектами i надмірні обсяги даних, що представлені мультимедійними засобами, можуть відволікати увагу учнів у процесі навчання;

- рівень використання вчителями мультимедіа для розробки відеоуроків усе ще дуже низький;

- вимагається відповідність між апаратними засобами і програмним забезпеченням, так як останні мають високу ресурсоємність.

Нині використання мережі Інтернет надає широкі можливості щодо створення й застосування готових відеоресурсів. Сервіс Lync (Skype Pro) входить до пакета 
MS Office 365, і є компонентом хмаро орієнтованого навчального середовища. Використання даного сервісу може допомогти вчителю у підготовці навчального відео, що зробить звичайний урок дійсно цікавим [16; 17].

Використовуючи сервіс Lync (Skype Pro), учитель може самостійно створити відеоурок. Для цього вчителеві необхідно підготувати навчальні матеріали в електронному форматі (презентація, фото, посилання тощо), встановити мікрофон, відеокамеру (за потреби). Потім увімкнути «запис», відкривати послідовно один за одним матеріали, коментувати їх, а за потреби, вносити письмові пояснення під час запису. Після закінчення роботи зберегти створене відео і розмістити його у відеосховищі Video (рис. 1).

Технологія «перевернуте» навчання може містити в собі інші технології, що активізують пізнавальну діяльність учнів, розвивають пошукові й дослідницькі компетентності, створюють умови для реалізації ігрових моментів як під час проведення уроку, так і під час виконання домашніх завдань, що виконуються учнями у власному темпі й у зручний для них час.

Навчання учнів за допомогою технології веб-квесту спрямовано на підвищення пізнавального інтересу і посилення навчальної мотивації. Використання веб-квестів робить учня самостійним, учить орієнтуватися в різноманітних ситуаціях, сприяє розвитку пізнавальних, творчих навичок й умінь самостійно конструювати свої знання, орієнтуватися в інформаційному просторі, критично мислити, розвивати навички інформаційної діяльності [1].

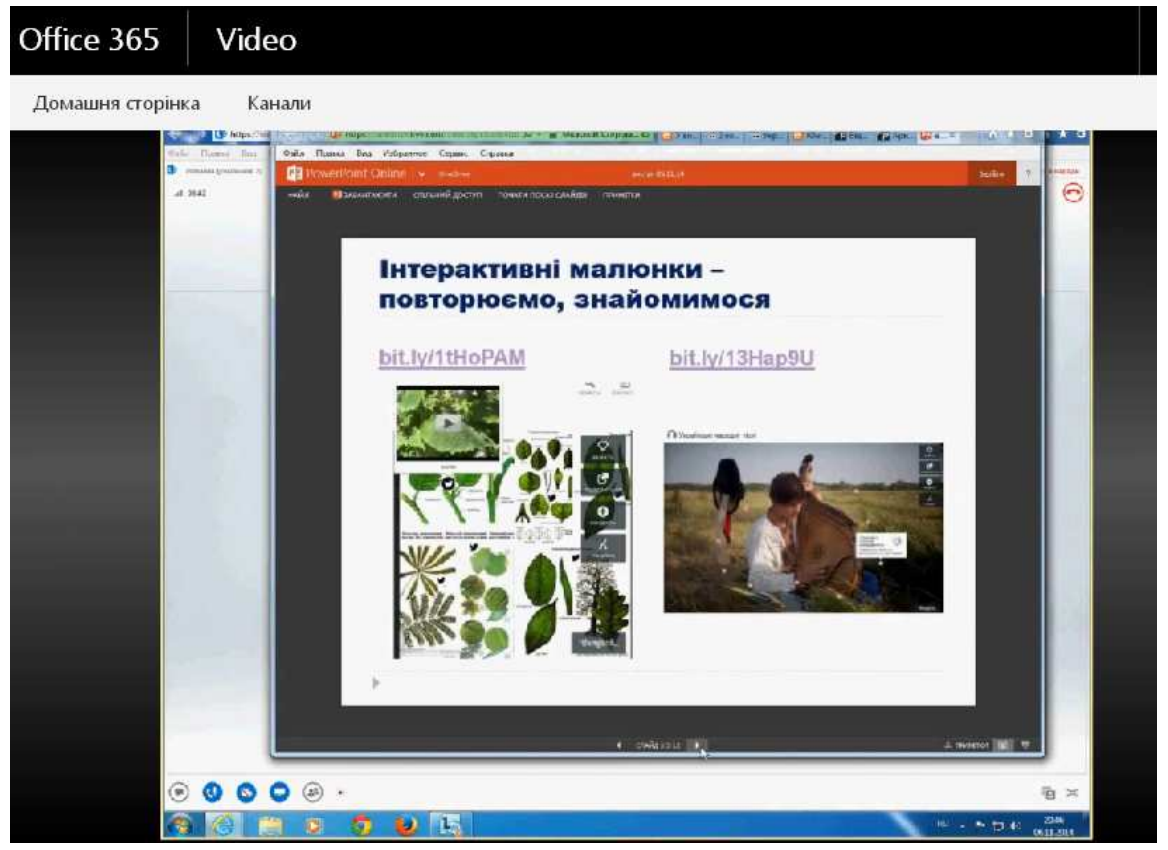

Рис. 1. Вікно демонстращії відеофрагменту в ХОНС

3 використанням технології веб-квесту вчитель отримує дієвий інструмент формування мотивації до навчання, творчого осмислення навчального матеріалу, ретельного закріплення учнями знань і їх ефективного контролю.

Методологічною основою веб-квесту є активне навчання, що створює передумови для перетворення нових даних, одержаних учнями, у нові знання, які вони можуть використовувати [3, с. 227].

Як зазначає Шмідт В. В., завдяки такому конструктивному підходу до навчання, учні не тільки добирають й упорядковують дані, отримані з мережі Інтернет, але й 
скеровують свою діяльність на поставлені перед ними завдання [23].

На думку Гапеєвої О., веб-квест має всі класичні ознаки інформаційної технології, оскільки покликаний забезпечити швидкий пошук даних, розосередження, доступ до джерел інформації незалежно від місця їх розташування. 3 іншого боку, він містить елементи ситуативної педагогічної технології - рольової гри, оскільки передбачає виконання конкретного завдання в ігровій формі [6].

Для розкриття особливостей використання технології веб-квесту у навчальному процесі необхідно визначити сутність поняття «веб-квест» (табл. 2). Існує два погляди вчених на поняття квесту: квест як освітній продукт і квест як технологія [10;27; 29].

Веб-квести розробляються для максимальної інтеграції мережі Інтернет в різні навчальні предмети на різних стадіях навчання, й охоплюють окрему проблему, навчальний предмет, тему [1].

3 розвитком ігрових технологій, зокрема веб-версій навчального призначення, під квестом (англ. Quest - подорож, мандрівка) стали розуміти комп'ютерну гру, у якій гравець має досягати певної мети, використовуючи власні знання і досвід, а також спілкуючись 3 учасниками квесту [12, с. 68].

Веб-квест поєднує в собі ідеї проектного методу й ігрових технологій.

Таблиия 2

\section{Визначення поняття «веб-квест» науковою спільнотою}

\begin{tabular}{|c|c|}
\hline Автор & Визначення \\
\hline Биховський Я. С. & $\begin{array}{l}\text { Сайт у мережі Інтернет, з яким працюють учні, виконуючи } \\
\text { ту чи іншу навчальну задачу [4] }\end{array}$ \\
\hline Базугіна О. I. & $\begin{array}{l}\text { Проблемне завдання-проект з елементами рольової гри, для } \\
\text { виконання якого використовуються інформаційні ресурси } \\
\text { мережі Інтернет [1] }\end{array}$ \\
\hline Волкова О. В. & $\begin{array}{l}\text { Вид інформаційних, проблемно-орієнтованих завдань } \\
\text { індивідуального або групового навчання, спрямованих на } \\
\text { формування і розвиток навичок пошукової і дослідницької } \\
\text { діяльності учнів у процесі освоєння, дослідження, обробки } \\
\text { та презентації мовного навчального матеріалу [5] }\end{array}$ \\
\hline Гончарова Н. Ю. & $\begin{array}{l}\text { Сценарій організації проектної діяльності учнів з будь-якої } \\
\text { теми з використанням ресурсів мережі Інтернет [8] }\end{array}$ \\
\hline Гриневич М. С. & Нова й перспективна технологія в медіа дидактиці [10] \\
\hline Сокол I. М. & $\begin{array}{l}\text { Ігрова технологія, яка має чітко поставлене дидактичне зав- } \\
\text { дання, ігровий задум, обов'язково має керівника } \\
\text { (наставника), чіткі правила, та реалізується } 3 \text { метою } \\
\text { підвищення в учнів рівня знань і вмінь, актуальних у } 21 \text { сто- } \\
\text { літті [24] }\end{array}$ \\
\hline $\begin{array}{l}\text { Федоров А. В., } \\
\text { Новікова А. О., } \\
\text { Колесніченко В. Л., } \\
\text { Каруна І. О. }\end{array}$ & $\begin{array}{l}\text { Освітній сайт, присвячений самостійній дослідницькій } \\
\text { роботі учнів (зазвичай, у групах) з певної теми з } \\
\text { гіперпосиланнями на різні веб-сторінки [26] }\end{array}$ \\
\hline $\begin{array}{l}\text { Кадемія М. Ю. } \\
\text { Яковенко А. В. }\end{array}$ & $\begin{array}{l}\text { Проблемне завдання з елементами рольової гри, для } \\
\text { виконання якого використовуються інформаційні ресурси } \\
\text { мережі Інтернет }[12 ; 30]\end{array}$ \\
\hline Кузнєцова Т. О. & $\begin{array}{l}\text { Приклад організації інтерактивного освітнього середовища } \\
\text { [14] }\end{array}$ \\
\hline
\end{tabular}




\begin{tabular}{|l|l|}
\hline Кононец Н. В. & $\begin{array}{l}\text { Сукупність методів і прийомів організації дослідницької } \\
\text { діяльності, для виконання якої студенти здійснюють пошук } \\
\text { інформації, використовуючи Інтернет-ресурси з практичною } \\
\text { метою [13] }\end{array}$ \\
\hline Шевцова О. Г. & $\begin{array}{l}\text { Технологія, орієнтована на розв’язання проблеми } \\
\text { діяльнісного підходу під час навчання [28] }\end{array}$ \\
\hline Шмідт В. В. & $\begin{array}{l}\text { Міні-проекти, засновані на пошуку інформації в мережі } \\
\text { Інтернет. [29] }\end{array}$ \\
\hline
\end{tabular}

Використання технології веб-квесту, на думку Ніколаєвої Н., є нескладним і не потребує завантаження додаткових програм або одержання специфічних технічних знань і навичок - необхідним є тільки комп'ютер із доступом до мережі Інтернет. Вона зазначає, що відповідно до методики веб-квесту учень навчається знаходити необхідні дані, здійснювати їх аналіз, систематизацію і розв'язувати поставлені завдання [19, с. 45].

Під веб-квестом ми розумісмо технологію самостійного активного навчання, щчо розвивається на принципах дослідницької діяльності з використанням ресурсів мережі Інтернет.

Як підкреслює Полат Є.С., для розвитку творчої, самостійної особистості необхідно мати не тільки значно більший обсяг даних, ніж той, який можуть надати вчитель, підручник і навчальні посібники, а ще мати варіативні відомості, які відображають різні точки зору, різні підходи до розв'язання одних і тих же проблем [21].

На думку Грабчак Д., функціональні можливості квестів дають змогу розв'язати ключові завдання навчальних предметів, зокрема стимулювати розвиток загальнонавчальних умінь і навичок учнів; поглибити знання з профільних предметів; підготувати до зовнішнього незалежного оцінювання, підсумкової атестації [9; 17].

Думку вченого підтверджують Напалков С. і Зайкін М., які розглядають веб-квест як розвиток пізнавальної самостійності учнів у вивченні навчальних тем 3 алгебри i геометрії. Вони зазначають, що активне впровадження Інтернет-технологій у навчальний процес сприяє досягненню додаткових освітніх цілей, пов'язаних 3 формуванням і розвитком здібностей учнів до самостійного пошуку, збору, аналізу і представлення в тому чи іншому вигляді даних, відомостей $[11 ; 17]$.

Кадемія М. акцентує увагу на таких властивостях веб-квесту як активне використанням мережі Інтернет у процесі дослідницької роботи [12].

Розглянемо основні характеристики технології веб-квест. Технологія веб-квесту розвивається на загальнонаукових і специфічних принципах. Так, на думку Мосіної М., інтеграція веб-квесту надає можливість реалізовувати як загальнодидактичні, так i методичні принципи навчання, зокрема, принципи інтерактивності, автономності й автентичності [18, с. 172], а Кругліков В. розвиває дане питання і визначає ще специфічні принципи індивідуалізації, гнучкості, контекстного підходу та розвитку співробітництва [18, с. 56].

Під час роботи школярів над веб-квестом реалізуються такі цุiлi: навчальна, розвивальна, виховна.

Навчальна передбачає залучення кожного учня до активного пізнавального процесу. Здійснюється організація індивідуальної і групової діяльності учнів, виявлення умінь і здібностей працювати самостійно відповідно до теми уроку (розділу).

Розвивальна передбачає розвиток інтересу учнів до навчального предмета. Разом 3 тим спостерігається розвиток творчих здібностей, уяви, логічного мислення; 
формування навичок дослідницької діяльності, публічних виступів, умінь самостійної роботи з різноманітними ресурсами; розширення кругозору, ерудиції.

Виховна передбачає виховання пунктуальності, толерантності, особистісної відповідальності за виконання роботи.

На думку Доджа Б., для досягнення поставленої навчальної мети, веб-квест повинен мати такі компоненти структури [35]:

- вступ (формулювання теми, опис головних ролей учасників, сценарій квесту, план роботи або усний огляд квесту);

- центральне завдання (завдання та/або питання, на які учасники мають знайти відповідь у межах самостійної роботи);

- список інформаційних ресурсів, які можна використати під час роботи, у тому числі ресурси мережі Інтернет;

- опис основних етапів роботи; керівництво до дії;

- узагальнення (підсумки роботи, розробка питань для подальшого поглиблення теми).

Розрізняють два типи веб-квестів: короткострокові i довгострокові. Короткострокові веб-квести розраховані на одне або кілька занять. Довгострокові розраховані на тривалий термін - це може бути окрема тема або кілька тем [20].

Застосування технології веб-квесту передбачає виконання таких функиій:

- навчання і робота в парах, групах, індивідуально;

- аналіз, синтез, оцінювання та використання різноманітних даних;

- оперування технологіями співпраці й кооперації;

- узагальнення і розробка нових знань.

Характерними особливостями технології веб-квесту є такі [3, с. 227]:

- заздалегідь визначаються ресурси, що містять дані, необхідні для розв’язання проблеми;

- однозначно визначається порядок дій, який має виконати учень для одержання необхідного результату;

- встановлюється перелік тих знань, умінь і навичок, які можуть здобути учні, виконавши даний веб-квест;

- однозначно визначаються критерії оцінювання виконання завдань.

Виконуючи веб-квест, можна реалізувати такі види завдань [35]:

- переказ - для демонстрації розуміння теми на основі подання матеріалів з різних джерел у новому форматі (створення презентації, плаката, розповіді);

- планування і проектування - для розробки плану або проекту на основі заданих умов:

- самопізнання - для дослідження будь-яких аспектів особистості;

- компіляція - для трансформації формату інформації, отриманої з різних джерел (створення книги кулінарних рецептів, віртуальної виставки, капсули часу, капсули культури);

- творче завдання - для створення п'єси, відеоролика або написання віршу, пісні;

- аналітичне завдання - для пошуку та систематизації даних;

- детектив, головоломка, таємнича історія - для формування висновків на основі суперечливих фактів;

- досягнення консенсусу - для вироблення рішення з гострої проблеми;

- оцінка - для обгрунтування певної точки зору;

- журналістське розслідування - для об'єктивного викладу даних (поділ думок i фактів);

- переконання - для схиляння на свій бік опонентів або нейтрально налаштованих осіб; 
- наукові дослідження - для вивчення різних явищ, відкриттів, фактів на основі унікальних он-лайн джерел.

Результати виконання веб-квесту, залежно від матеріалу, що досліджується, можуть бути представлені у вигляді усного виступу, мультимедійної презентації, есе, веб-сторінки, відеофрагменту тощо.

Оиінювання результатів виконання веб-квесту здійснюється за такими показниками: актуальність - як інформація, представлена у веб-квесті, співвідноситься 3 основною ідеєю дослідження; доступність - наскільки доступна для розуміння й сприйняття основна ідея творчої роботи; форма подачі - оригінальність творчого підходу, використання нових, переконливих форм і методів; ефективність впливу наскільки веб-квест зацікавлює, емоційно захоплює аудиторію; технічність - виконання технічних вимог, пред’явлених до роботи; завершеність проекту. [3, с. 228].

Eфективність використання веб-квесту можлива за таких умов:

- веб-квест використовується для отримання або узагальнення знань учнів з будьякої теми навчання, у межах проміжного або підсумкового контролю;

- виконання веб-квесту супроводжується тренувальними вправами на основі ретельно підібраного навчального матеріалу, що забезпечують розвиток предметних компетентностей учнів $[1 ; 39 ; 40 ; 41 ; 42 ; 43]$.

Сучасні технології, такі як MS Office 365, дозволяють створювати веб-квести 3 використанням сервісу OneNote, забезпечуючи доступ одному учню, малій групі учнів або всім, хто має посилання на даний електронний документ (рис. 2).

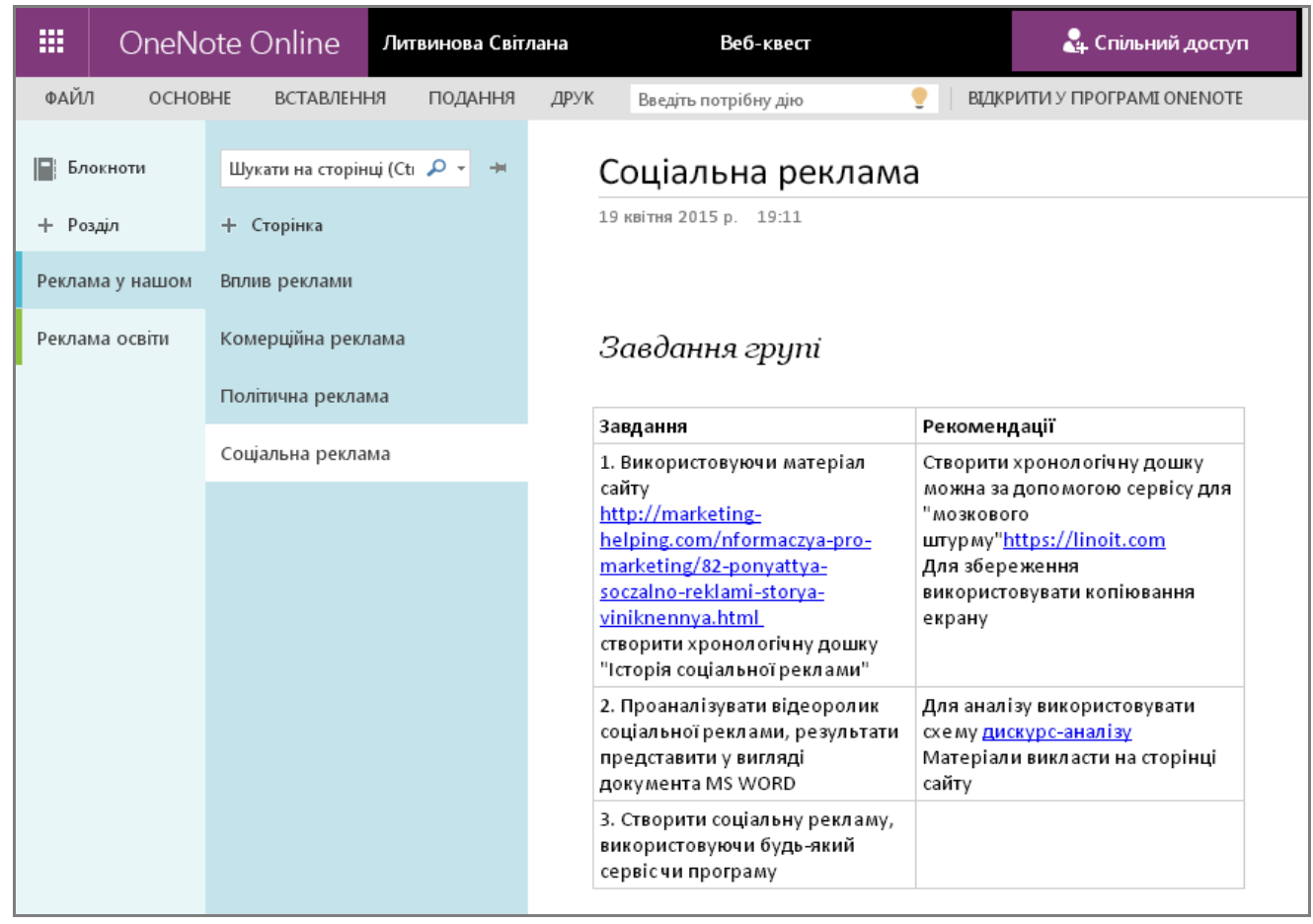

Рис. 2. Приклад створення веб-квесту за допомогою сервісу OneNote

До особливостей технології веб-квесту можна віднести той факт, що у ході виконання завдань учні можуть працювати в індивідуальному темпі, повертаючись до матеріалу, який не достатньо засвоєний раніше. Реалізація такого підходу до навчання збагачує можливості вчителя, дозволяючи йому індивідуалізувати навчальний процес. Індивідуалізація тут, насамперед, пов'язана 3 урахуванням попередньої підготовки учнів (рівня їхніх знань й умінь), 3 диференціюванням за психологічними 
особливостями (темпераменту, характеру протікання розумових процесів, навченості, швидкості роботи 3 навчальним матеріалом). У спеціально створених умовах ці навчальні завдання сприятимуть розвитку, поглибленню, зміцненню знань учнів [1].

Узагальнюючи дані про технологію, здійснимо класифікацію веб-квестів за:

- кількістю учасників: індивідуальні, групові, масові;

- складністю: прості, середні, складні;

- дидактичною метою: узагальнюючі, пізнавальні, розвивальні, інформативні;

- видом діяльності: дослідницькі, пошукові, рольові, ігрові, творчі;

- формою проведення: веб-квести; QR-квести; відео-квести; фото-квести;

- тривалістю: короткострокові, довгострокові;

- тематикою: предметні, міжпредметні;

- структурою: послідовні, етапні, кругові;

- результатом: твори, есе, презентації, доповіді, відеофрагменти тощо.

Серед особливостей застосування ефективних організаційних i навчальних технологій «перевернутого» навчання і веб-квесту у хмаро орієнтованому навчальному середовищі загальноосвітнього навчального закладу варто зазначити такі: вони мало поширені в системі загальної середньої освіти; учителю необхідно мати додатковий час на підготовку, відбір ресурсів, запис відеофрагментів тощо; у школах низька якість Інтернет-зв’ язку; учителеві потрібен додатковий час на опанування даних технологій.

\section{4. ВИСНОВКИ ТА ПЕРСПЕКТИВИ ПОДАЛЬШИХ ДОСЛІДЖЕНЬ}

У хмаро орієнтованому навчальному середовищі не тільки створюються умови повсюдного доступу до навчальних матеріалів, а й реалізуються технології «перевернутого» навчання і веб-квест для задоволення різних навчальних, виховних, розвивальних потреб учнів і вчителів загальноосвітніх навчальних закладів.

Використання хмаро орієнтованого навчального середовища дає вчителю можливість проводити інноваційні уроки за новими формами. Аналіз передового педагогічного досвіду зарубіжних і вітчизняних педагогів показав, що за допомогою технологій «перевернутого» навчання і веб-квесту розв' язується низка найважливіших проблем навчання - забезпечення безперервної інтенсивної навчальної комунікації за межами загальноосвітнього навчального закладу й активізація навчальної діяльності учнів, а хмаро орієнтоване навчальне середовище $\epsilon$ незамінним компонентом цього процесу.

Важливим аспектом використання хмаро орієнтованого навчального середовища $€$ його насиченість різноманітними сервісами, інтегративність із зовнішніми сервісами, можливість реалізації передових освітніх технологій, значна економія на закупівлі і систематичному оновленні програмного забезпечення, парку комп'ютерної техніки й енергозбереженні.

Подальшого дослідження потребують такі питання: ефективність використання сервісів MS Office 365 для реалізації навчальних цілей, формування IКТкомпетентності вчителів і учнів у процесі використання спроектованого хмаро орієнтованого навчального середовища.

\section{СПИСОК ВИКОРИСТАНИХ ДЖЕРЕЛ}

1. Багузина Е. И. Веб-квест технология как дидактическое средство формирования иноязычной коммуникативной компетентности : дисс. ... кандидата пед. наук : 13.00.01 / Е. И. Багузина. Москва, 2011. - 238 с. 
2. Басалгина Т. Ю. Технология «Перевернутый класс» при изучении специальных дисциплин / Т. Ю. Басалгина // Профессиональное образование: проблемы и перспективы развития : материалы V краевой заочной научно-практической конференции (г. Пермь, 17 октября 2014 года). - С. 173-175

3. Бондаренко Т. М. Веб-квест технологія як засіб активізації самостійної діяльності майбутніх вчителів початкових класів / Т. М. Бондаренко // Вісник ЛНУ імені Тараса Шевченка. - № 13 (272), Ч. II. - 2013. - C. 224-230

4. Быховский Я. С. Образовательные веб-квесты. Конгресс конференций. Сайт «Информационные технологии в образовании». [Электронный ресурс] / Я. С .Быховский. - Режим доступа : http://ito.edu.ru/1999/III/1/30015.html. - Назва з екрана.

5. Волкова О. В. Подготовка будущего специалиста к межкультурной коммуникации с использованием технологии веб-квестов : дисс. ... канд. пед. наук : 13.00.08 / Волкова О. В. Белгород, 2010. - 217 с.

6. Гапеєва О. Л. WebQuest технологія у навчанні студентів за програмою підготовки офіцерів запасу / О. Л. Гапеєва // Науковий вісник НЛТУ України : зб. наук.-техн. праць. - 2011. - Вип.21.1. - С. 335-340.

7. Глазунова О. Г. Теоретико-методичні засади проектування та застосування системи електронного навчання майбутніх фахівців 3 інформаційних технологій в університетах аграрного профілю : дис.... д-ра пед. наук : 13.00.10 / Глазунова О. Г. - К., 2015. - 545c.

8. Гончарова Н. Ю. Новые информационные технологии на занятиях по иностранному языку в неязыковом вузе [Электронный ресурс] / Гончарова Н. Ю. - Режим доступа : http://smrgaki.ru/8/4/1_5/4.htm. - Назва з екрана.

9. Грабчак Д. В. Освітній веб-квест як нова Інтернет-технологія навчання елективних курсів 3 фізики [Електронний ресурс] / Д. В. Грабчак // Інформаційні технології навчання в освіті. - Режим доступу : http://ite.kspu.edu/webfm_send/299, вільний. - Назва з екрана.

10.Гриневич М. С. Медіаосвітні квести... //Вища освіта України. 2009. № 3. Дод. 1. Тем. Вип. Педагогіка вищої школи: методологія, теорія, технології. - К. : Гнозис, 2009. - С. 153-155.

11. Зайкин М. И. Об общей структуре и содержательной специфику тематического образовательного веб-квеста по математике / Зайкин М. И., Напалков С. В. // Издательский Дом "Академия Естествознания". - 2013. - №5. - С. 233.

12. Кадемія М. Ю. Інноваційні технології навчання: словник-глосарій : [навчальний посібник для студентів, викладачів] / М. Ю. Кадемія, Л. С. Євсюкова, Т. В. Ткаченко. - Львів : Вид-во «СПОЛОМ», 2011. - 196 с.

13. Кононец Н. В. Технологія вебквест у контексті ресурсно-орієнтованого навчання студентів [Електронний ресурс] / Н. В. Кононец // Режим доступу : http://www.rusnauka.com/4_SND_2013/Pedagogica/5_123956.doc. - Назва з екрана.

14. Кузнецова Т. А. Технология веб-квест как интерактивная образовательная середа / Т. А. Кузнецова // ИТО-Иваново-2011. Секция 2. [Электронный ресурс]. - Режим доступа : http://ito.edu.ru/2011/Ivanovo/II/II-0-12.html. - Название с экрана.

15. Курвитс М. Модель "Перевернутый класс". Что переворачиваем? / Марина Курвитс, Юрий Курвитс // Управление школой. - 2014. - № 7/8. - С. 38-40

16. Литвинова С. Г. Поняття та основні характеристики хмаро орієнтованого навчального середовища середньої школи [Електронний ресурс] / С. Г. Литвинова // Інформаційні технології і засоби навчання: електронне наукове фахове видання. - 2014. - №2 (40). - С. 26-41 - Режим доступу : http://journal.iitta.gov.ua/index.php/itlt/article/view/970/756\#.U2aW6IF_vzA. - Назва з екрана.

17. Моделювання й інтеграція сервісів хмаро орієнтованого навчального середовища : монографія / за заг.ред. С. Г. Литвинової. - К. : ЦП «Компринт», 2015. - С. 86,

18. Мосина М. А. Веб-квест как средство организации учебной деятельности студентов в системе дистанционного обучения / М. А. Мосина // Иностранные языки дистанционном обучении : материалы II Международной научно-практической конференции (Пермь, 6-8 февраля 2006 г.). Пермь, 2006. - С. 170-175.

19. Николаева Н. В. Образовательные веб-квесты как метод и средство развития навыков информационной деятельности учащихся [Електронний ресурс] / Николаева Н. В. // Вопросы Интернет-образования. - 2002. - № 7. - Режим доступу : http://vio.fio.ru_07. - Назва з екрана.

20. Николайчук И. В. Дидактические особенности образовательных веб-квестов. [Электронный peсурс]. - Режим доступа : razrabotki/obrazovatelnii_veb-kvest/. - Назва з екрана.

21. Полат Е. С. Интернет в гуманитарном образовании / Е. С. Полат и др.; под ред. Е. С. Полат. М.: ВЛАДОС, 2001. - 272 с. 
22. Ремизова Е. Г. Реализация методики смешанного обучения по модели «перевернутый класс» на уроках інформатики [Електронний ресурс] / Е. Г. Ремизова. - Режим доступа : http://msk.ito.edu.ru/2014/section/229/94840/. - Назва з екрана.

23. Сокол И. Н. Классификация квестов / И. Н. Сокол // Молодий вчений. - 2014. - № 6 (09). - С. 138 140

24. Сокол І. М. Квест: метод чи технологія? / І. М. Сокол // Компютер у школі та сім’ї. - 2014. - № 2. С. $28-32$.

25. Сокол І. М. Впровадження квест-технології в освітній процесс : навч.посіб. / І. М. Сокол. Запоріжжя :Вид-во Акцент Інвест-трейд, 2014. - 108 с.

26. Федоров А. В., Новикова А. А., Колесниченко В. Л., Каруна И. А. Медиаобразование в США, Канаде и Великобритании. - Таганрог : Изд-во Кучма, 2007. - 256 с.

27. Шаматонова Г. Л. Веб-квест как интерактивная методика обучения будущих специалистов по социальной работе / Г. Л. Шаматонова // „SOCIOпростір: Междисциплинарный сборник научных работ по социологии и социальной работе”. - 2010. - № 1. - С. 234-236.

28. Шевцова О. Г. Веб-квест - один из наиболее эффективных способов применения Интернета для внедрения ролевых игр в обучение [Электронный ресурс] / Шевцова О. Г. - ИТО-2008. Секция III. Подсекция 2 Владивостокский государственный университет экономики и сервиса (ВГУЭС), г. Владивосток. - Режим доступа : http://ito.edu.ru/2008/Moscow/III/2/III-2-7656.html. - Назва 3 екрана.

29. Шмідт В. В. Технологія веб-квеста при навчанні англійської мови студентів немовних спеціальностей [Електронний ресурс] / В. В. Шмідт. - Режим доступу : http://winner.seua.net/page26/1/10/ . - Назва з екрана.

30. Яковенко А. В. Использование технологии Web-quest в языковом образовании. [Электронный ресурс] / A. $\mathrm{B}$. Яковенко http://www.rusnauka.com/5_SWMN_2012/Pedagogica/1_100769.doc.htm. - Назва 3 екрана.

31. Baker, Celia. (2012, November 25). Flipped classrooms: Turning learning upside down: Trend of "flipping classrooms" helps teachers to personalize education / Celia Baker. Deseret News. (online). Available from : http:// www.deseretnews.com/article/765616415/Flipped-classrooms-Turning-learningupside-down. html?pg=all.

32. Bergmann, J., Sams A. "Flip Your Classroom: Reach Every Student in Every Class Every Day”, [online] / ISTE. (online). - Available from : http://www.iste.org/store/product?ID=2285.

33. Berrett, D. (2012, February 19). How 'flipping' the classroom can improve the traditional lecture. The Chronicle of Higher Education (online). - Available from : http://chronicle.com/article/How-Flippingthe- Classroom/130857/.

34. Byrne, D. Blended learning (online) / D. Byrne. - Available from : http://www.trainings.ru/library/articles/?id=6249.

35. Dodge, Bernie Some Thoughts About WebQuests (online) / Bernie Dodge // WebQuest.org. - 1995. Available from : http://webquest.sdsu.edu/about_webquests.html, free.

36. Driscoll, Tom. (2012). Flipped Learning and democratic Education: The Complete Report. (online) / Tom Driscoll. - Available from : http:// www.flipped-history.com/2012/12/flipped-learning-democraticeducation.html.

37. Gorman, M. (2012, July 18). Flipping the classroom...a goldmine of research and resources keep you on your feet. (online) / M. Gorman. - Available from : http://21 centuryedtech.wordpress.com/.

38. Green, G. (2012, July). The Flipped Classroom and School Approach: Clintondale High School. Presented at the annual Building Learning Communities Education Conference, Boston, MA. (online) / G. Green. - Available from : http://2012.blcconference.com/documents/flipped-classroom-schoolapproach.pdf.

39. Lamb, A. Locate and Evaluate WebQuests. 2000-2004 / EduScapes. Teacher Tap. Internet resourses.Webquests (online) / A. Lamb. - Available from : http://eduscapes.com/tap/topic4.htm.

40. Lynn, Laurence E. Teaching and Learning with Cases / Laurence L.E. - A Guidebook. Chatham House Publishers, Seven Bridges Press, LLC, 1999. - P. 45.

41. March, T. (2003). Criteria for Assessing Best WebQuests (online) / T. March. - Available from : http://www.bestwebquests.com/bwq/matrix.asp.

42. Marshall, H. W. (2013, March 21). Three reasons to flip your classroom / H. W. Marshall (online). Available from : http://www.slideshare.net/lainemarsh/3-reasons-to-flip-tesol-2013-32113.

43. Rogers, C. R. (1983). Freedom to learn for the 80's / C. R. Rogers. - Columbus, OH: Merrill.

44. Stern, H. H. (1983). Fundamental Concepts of Language Teaching / H. H. Stern. - Oxf.Univ.Press.

Матеріал надійшов до редакиії 25.04.2015 p. 


\title{
ТЕХНОЛОГИИ ОБУЧЕНИЯ УЧАЩИХСЯ В ОБЛАЧНО ОРИЕНТИРОВАННОЙ УЧЕБНОЙ СРЕДЕ ОБЩЕОБРАЗОВАТЕЛЬНЫХ УЧЕБНЫХ ЗАВЕДЕНИЙ
}

\author{
Литвинова Светлана Григорьевна \\ кандидат педагогических наук, старший научный сотрудник \\ Институт информационных технологий и средств обучения НАПН Украины, г. Киев, Украина \\ s_litvinova@i.ua
}

\begin{abstract}
Аннотация. В статье проанализировано технологию «перевернутого» обучения, выяснены особенности данной технологии, проведено сравнение с традиционным обучением, описаны особенности использования технологии учителем и учениками, разработана технологическая карта подготовки к уроку учителя и ученика, установлено, что компонент облачно ориентированного учебной среды Lync (Skype Pro) может использоваться для разработки видеофрагментов с целью реализации технологии «перевернутого» обучения.

Автором дано определение понятию «технология веб-квест», обобщенны компоненты структуры веб-квеста, определены функции, виды задач, решаемых с использованием данной технологии, осуществлена классификация веб-квестов. Установлено, что в облачно ориентированной учебной среде заложены все возможности для реализации технологии веб-квеста.
\end{abstract}

Ключевые слова: облачно ориентированная; учебная среда; технологии; перевернутое обучение; веб-квест; ООУС.

\section{LEARNING TECHNOLOGIES FOR STUDENTS IN THE CLOUD ORIENTED LEARNING ENVIRONMENT OF COMPREHENSIVE EDUCATIONAL INSTITUTIONS}

\section{Svitlana G. Lytvynova}

$\mathrm{PhD}$ (pedagogical sciences), senior researcher

Institute of Information Technologies and Learning Tools of NAES of Ukraine, Kyiv, Ukraine s_litvinova@i.ua

\begin{abstract}
The paper analyzes the «flipped» learning and «Web Quest» technologies. The features of the «flipped» learning technology are generalized, as well as compared with traditional learning, clarified the benefits of the technology for teachers and students, described the features of the technology used by teacher and students, developed a teacher's and student's flow chart for preparation to the lesson, generalized control and motivation components for activating learning activities of students, found out that a component of cloud oriented learning environment (COLE) - Lync (Skype Pro) can be used to develop video clips and support «flipped» learning technology. The author defines the concept of «Web Quest» technology, generalizes the «Web Quest» structure components. In the article the functions, features of this technology, the types of problems that can be solved with the help of this technology, as well as «Web Quest» classification are presented. It has been found out that the cloud oriented learning environment gives all the possibilities for «Web Quest» technology implementation in teaching of different subjects of all branches of science.

With the help of «flipped» technology training and «Web Quest» a number of important problems of education can be solved - providing the continuous communication intensive training beyond general educational establishment and activation of learning activities of students.
\end{abstract}

Keywords: cloudy oriented; learning environment; technology; flipped training; Web Quest; COLE.

\section{REFERENCES (TRANSLATED AND TRANSLITERATED)}

1. Baguzina E. I. Web quest technology as a didactic means of formation of foreign language communicative competence: diss. ... Candidate ped. Sciences: 13.00.01 / E. I. Baguzina. - Moscow, 2011. -238 p. (in Russian). 
2. Basalgina T. Yu Tecology "Flipped class" in the study of special subjects / T. Y. Basalgina // Vocational Education: Problems and Prospects Proceedings of the V boundary correspondence scientific-practical conference (Perm, 17 October 2014). - P. 173-175 (in Russian).

3. Bondarenko T. N. Web Quest technology as a means of self-activation of future primary school teachers / T. N. Bondarenko // Bulletin of LNU. - № 13 (272), Part II. - 2013. - P. 224-230 (in Ukrainian).

4. Bykhovsky Y. S. Educational Web quests. Congress conferences. Site "Information Technologies in Education". [online]. - Available from : http://ito.edu.ru/1999/III/1/30015.html (in Russian).

5. Volkova O. V. training of future specialists in intercultural communication using the technology of web quests: diss. ... Candidate ped. Sciences: 13.00.08 / Volkova O. V. - Belgorod, 2010. - 217 p. (in Russian).

6. Hapeyeva O. L. WebQuest technology in teaching students program for reserve officers / O. L. Hapeyeva // Scientific Bulletin NLTU Ukraine: Coll. scientific-technical. works. - 2011. - Vyp.21.1. - P. 335-340 (in Ukrainian).

7. Glazunov O. G. Theoretical and methodological principles of design and application of e-learning future professionals in the agricultural universities dis ... profile. Dr. ped. Sciences .: 13.00.10 / Glazunov O. G. - K., 2015. - 545 p. (in Ukrainian).

8. Goncharova N. Y. New information technologies in the classroom for foreign language in not language high school [online]. - Available from : http://smrgaki.ru/8/4/1_5/4.htm (in Russian).

9. Grabchak D. V. Educational your quest as a new Internet technology education elective courses in physics [online] // Instructional education. - Available from : http://ite.kspu.edu/webfm_send/299, free (in Ukrainian).

10. Hrynevych M. S. Media Quests ... // Higher education Ukraine. 2009. № 3. Ext. 1. Topics. Vol. Educator Country higher education: methodology, theory and technology. - K. : Gnosis, 2009. - P. 153-155 (in Ukrainian).

11. Zaykin M. I. The overall structure and specific content of the thematic educational web quest in mathematics / M. I. Zaykin, S. V. Napalkov // Publishing House "Academy of Natural History." - 2013. №5. - P. 233 (in Russian).

12. Kademiya M. innovative learning technologies: Dictionary and Glossary: [textbook for students, faculty] / M. Kademiya, L.S. Evsukova, T. Tkachenko. - Lviv : Izd "spol", 2011. - 196 p. (in Ukrainian).

13. Kononets N. V. vebkvest technology in the context of resource-based learning students [online] / N. V. Kononets. - Available from :http://www.rusnauka.com/4_SND_2013/Pedagogica/5_123956.doc (in Ukrainian).

14. Kuznetsova T. A. Technology web quest as an interactive educational environment [online] // ITOIvanovo-2011 / Section 2. - Available from : http://ito.edu.ru/2011/Ivanovo/II/II-0-12.html (in Ukrainian).

15. Kurvits M. Model "Inverted class." What overturn? [Text] / Marina Kurvits, Urey Kurvits // Management School. - 2014. - № 7/8. - P. 38-40 (in Russian).

16. Lytvynova S. G. Concepts and characristics of cloud oriented learning environment of school [online] / S. G. Lytvynova // Informatsiyni tehnologii i zasobi navchannya: E-Naukova fahove Vidanov. - 2014. - №2 (40). $\quad-\quad$ P. $\quad$ P. 26-41. $\quad-\quad$ Available from http://journal.iitta.gov.ua/index.php/itlt/article/view/970/756\#.U2aW6IF_vzA (in Ukrainian).

17. The modeling and integration of cloud orient learning environment : monograph / Society. ed. S. G. Lytvynova. - K. : CB "Komprynt", 2015. - p.86 (in Ukrainian).

18. Mosin M. A. WebQuest as a means of organizing learning activities of students in distance learning system / M. A. Mosin // Foreign languages Distance learning : materials II International Scientific and Practical Conference (Perm, 6-8 February 2006 ). - Perm, 2006. - P. 170-175 (in Russian).

19. Nikolaev N.V. Educational WebQuest as a method and means of developing the skills of information activity of students [online] / Nikolaev NV // Questions of online education. - 2002. - № 7. - Available from :http://vio.fio.ru_07 (in Russian)

20. Nikolaichuk I. V. Didactic features educational web quests [online]. - Available from : http://innanikolaichuk.narod2.ru/Metodicheskie_razrabotki/obrazovatelnii_veb-kvest/ (in Russian).

21. Polat E. S. Internet in humanities / E. S. Polat, etc .; Ed. E. S. Polat. - M. : VLADOS, 2001. - 272 p. (in Russian).

22. Remizov E. G. Implementation techniques blended learning model "flipped classroom" in the classroom informatiki [online]. - Available from : http://msk.ito.edu.ru/2014/section/229/94840/ (in Russian).

23. Sokol I. N. Classification of quests / I. N. Falcon // Young Falcon vcheny. - 2014 . - № 6 (09). - S. 138140 (in Russian).

24. Sokol I. N. Quest: method or technology? / I. N. Sokol // Kompyuter at school and family. - 2014. - № 2. - P. 28-32 (in Ukrainian). 
25. Sokol I. N. Implementation quest technologies in the educational process : navch.posib. / I. N. Sokol. Brussels : Izd Accent Invest-trade, 2014. - 108 p. (in Ukrainian).

26. Fedorov A. V. Media Education in the United States, Canada and the UK / A. V. Fedorov, A. A. Novikov, V. L. Kolesnichenko, I. A. Karuna. - Taganrog : Publishing House of Kuchma, 2007. 256 p. (in Russian).

27. Shamatonova G. L. WebQuest as an interactive methods of teaching future experts in social work / G. L. Shamatonova // "SOCIOprostir: Interdisciplinary collection of scientific works on the sociology and social work." - 2010. -№ 1. - P. 234-236 (in Russian).

28. Shevtsova O. G. Web Quest - one of the most effective ways to use the Internet for implementation of role-playing games in education [online] / ITO-2008 / Section III / Subsection 2 Vladivostok State University of Economics and Service (VSUES), Vladivostok. - Available from : http://ito.edu.ru/2008/Moscow/III/2/III-2-7656.html (in Russian).

29. Schmidt V. V. Technology Web quest in learning English students of non-linguistic specialties [online]. Available from : http://winner.se-ua.net/page26/1/10/ (in Ukrainian).

30. Yakovenko A. V. Using technology Web-quest in language education [online]. - Available from : http://www.rusnauka.com/5_SWMN_2012/Pedagogica/1_100769.doc.htm (in Russian).

31. Baker, Celia. (2012, November 25). Flipped classrooms: Turning learning upside down: Trend of "flipping classrooms" helps teachers to personalize education / Celia Baker. Deseret News [online]. Available from : http:// www.deseretnews.com/article/765616415/Flipped-classrooms-Turning-learningupside-down. html?pg=all. (in English)

32. Bergmann, J., Sams A. "Flip Your Classroom: Reach Every Student in Every Class Every Day”, [online] / ISTE. - Available from : http://www.iste.org/store/product?ID=2285. (in English)

33. Berrett, D. (2012, February 19). How 'flipping' the classroom can improve the traditional lecture. The Chronicle of Higher Education [online]. - Available from : http://chronicle.com/article/How-Flippingthe- Classroom/130857/.(in English)

34. Byrne, D. Blended learning [online] / D. Byrne. - Available from : http://www.trainings.ru/library/articles/?id=6249. (in English)

35. Dodge, Bernie Some Thoughts About WebQuests [online] / Bernie Dodge // WebQuest.org. - 1995. Available from : http://webquest.sdsu.edu/about_webquests.html, free. (in English)

36. Driscoll, Tom. (2012). Flipped Learning and democratic Education: The Complete Report [online] / Tom Driscoll. - Available from : http:// www.flipped-history.com/2012/12/flipped-learning-democraticeducation.html. (in English)

37. Gorman, M. (2012, July 18). Flipping the classroom...a goldmine of research and resources keep you on your feet [online] / M. Gorman. - Available from : http://21 centuryedtech.wordpress.com/. (in English)

38. Green, G. (2012, July). The Flipped Classroom and School Approach: Clintondale High School. Presented at the annual Building Learning Communities Education Conference, Boston, MA [online] / G. Green. - Available from : http://2012.blcconference.com/documents/flipped-classroom-schoolapproach.pdf. (in English)

39. Lamb, A. Locate and Evaluate WebQuests. 2000-2004 / EduScapes. Teacher Tap. Internet resourses.Webquests [online] / A. Lamb. - Available from : http://eduscapes.com/tap/topic4.htm. (in English)

40. Lynn, Laurence E. Teaching and Learning with Cases / Laurence L.E. - A Guidebook. Chatham House Publishers, Seven Bridges Press, LLC, 1999. - P. 45. (in English)

41. March, T. (2003). Criteria for Assessing Best WebQuests [online] / T. March. - Available from : http://www.bestwebquests.com/bwq/matrix.asp. (in English)

42. Marshall, H. W. (2013, March 21). Three reasons to flip your classroom [online] / H. W. Marshall. Available from : http://www.slideshare.net/lainemarsh/3-reasons-to-flip-tesol-2013-32113. (in English)

43. Rogers, C. R. (1983). Freedom to learn for the 80's / C. R. Rogers. - Columbus, OH: Merrill. (in English)

44. Stern, H. H. (1983). Fundamental Concepts of Language Teaching / H. H. Stern. - Oxf.Univ.Press. (in English) 